\title{
Emerging technologies. Analysis and current perspectives
}

\author{
Miriam Agreda Montoro \\ magreda@ujaen.es \\ University of Jaén, Spain \\ Ana Ma Ortiz Colón \\ aortiz@ujaen.es \\ University of Jaén, Spain
}

\author{
Javier Rodríguez Moreno \\ jrmoreno@ujaen.es \\ University of Jaén, Spain \\ Karl Steffens \\ Karl.Steffens@uni-koeln.de \\ University of Koln, Germany
}

\begin{abstract}
The convergence in the use of technology in classrooms and the development of new methodologies have involved a redefinition of the different educational agents' performance, for the upcoming Horizon reports to generate a radiography of the emerging technological trends that will have an impact in the upcoming years. As a consequence, we will focus on adaptative learning technologies based on the perspectives of profound learning, where the achievement of objectives will be reflected through generated learning analytics, whose association may produce consistent verifiable blockchains. For that matter, this work proposes a meta-analysis of 62 research studies indexed in the WOS and Scopus databases during 2013 and 2018, in the area of Social Sciences, taking as descriptors the technologies mentioned in those reports. A search strategy based on four different criteria has been used: public (target), topic, methodological design and main conclusions.
\end{abstract}

\section{Keywords}

Emerging Technologies; Literature Review; Deep Learning; Collaborative Learning; Adaptative Learning; Learning Analytics; e-learning. 


\section{Introduction}

Emerging technologies (ET) have generated plenty of debates within the academic spheres, becoming the central subject of many initiatives and political discussion forums. It is necessary to take into account that most of the studies agree when defining the peculiarities attached to a specific ET; however its impact is highlighted when referring to its impact in education, economy and society(Porter, 2004; Porter \& Detampel, 1995). On the other hand, Martin $(1995,2010)$ understands them from the point of view of their generic properties. Other authors, however, remark the trascendence that ETs possess when they are linked to the processes of emergency, the sustainability, their innovative nature and their continuous evolution (Bettencourt, Kaiser, Kaur, Castillo-Chávez, \& Wojick, 2008; Geels, 2005; Markard, Raven, \& Truffer, 2012; Small, Boyack, \& Klavans, 2014).

Therefore, all considerations towards what ETs are, will be closely linked to the researcher's perspective, from an approach that insists on determining their characteristics and central elements, or their socioeconomic and cultural impact (Adner \& Lenvinthal, 2002; Avila-Robinson \& Miyazaki, 2011). Others, however, consider them an extension of actual technology itself (Leu, Kinzer, Coiro, \& Cammack, 2004; Markard et al., 2012; Shen, Chang, Lin, \& Yu, 2010). This lack of consensus may come from the eclecticism and ad hoc nature of the research studies, developed from various areas of knowledge (Halaweh, 2013; Rotolo, Hicks, \& Martin, 2015). Given these difficulties, the development of methodological approaches has been emphasized from the perspective of Scientometrics, which aims to delimit, detect and examine all emergence aspects in Technology and Science (Boyack, Small, \& Klavans, 2013; Glänzel \& Thijs, 2011; Small, 2006).

In this light, ETs are considered to be a science based on innovation, which enables the creation of a new industry or transform the existing one (Day, Schoemaker, \& Gunther, 2004; Srinivasan, 2008). They are also defined as those new technologies that are being continuously developed or will be developed during the next five or ten years. These mentioned technologies will have a great influence on both financial and social environments (The Business Dictionary, 2018). Taking this definition into account, we tend to think that any new technology could be considered as "emerging". This is not fully right, given the fact that there are technologies that may be seen as "emerging", regarding their area of knowledge, their geographical situation, their use or their implementation. If we look at the invention of the World Wide Web, which was created back in the 90s (Berners Lee, Cailliau, Pollermann, \& Groff, 1992), it can no longer be considered an ET. However, web 2.0 and web 3.0, as well as their subsequent generations, and their respective uses, are considered to be ETs (Nupur, 2014). Stahl (2011) based his research on the impact of ETs over Ethics. From that, he defines them as those technologies that will become especially relevant in the upcoming 10 or 15 years.

Halaweh (2013) concludes that all technology that is not used in a specific context may be considered as ET given their lack of a limited lifetime. Consequently, it is believed that this is caused by disruptive transformations in the fields where human beings are developed.

\section{a. Emerging technologies in the area of education}

The idea of technology as the axiom of the world and the current society, as well as its importance in educational contexts, has been shown thanks to the appearance of many studies and researches where the main topics were ETs in education, especially during the last decade (Figure 1.). 


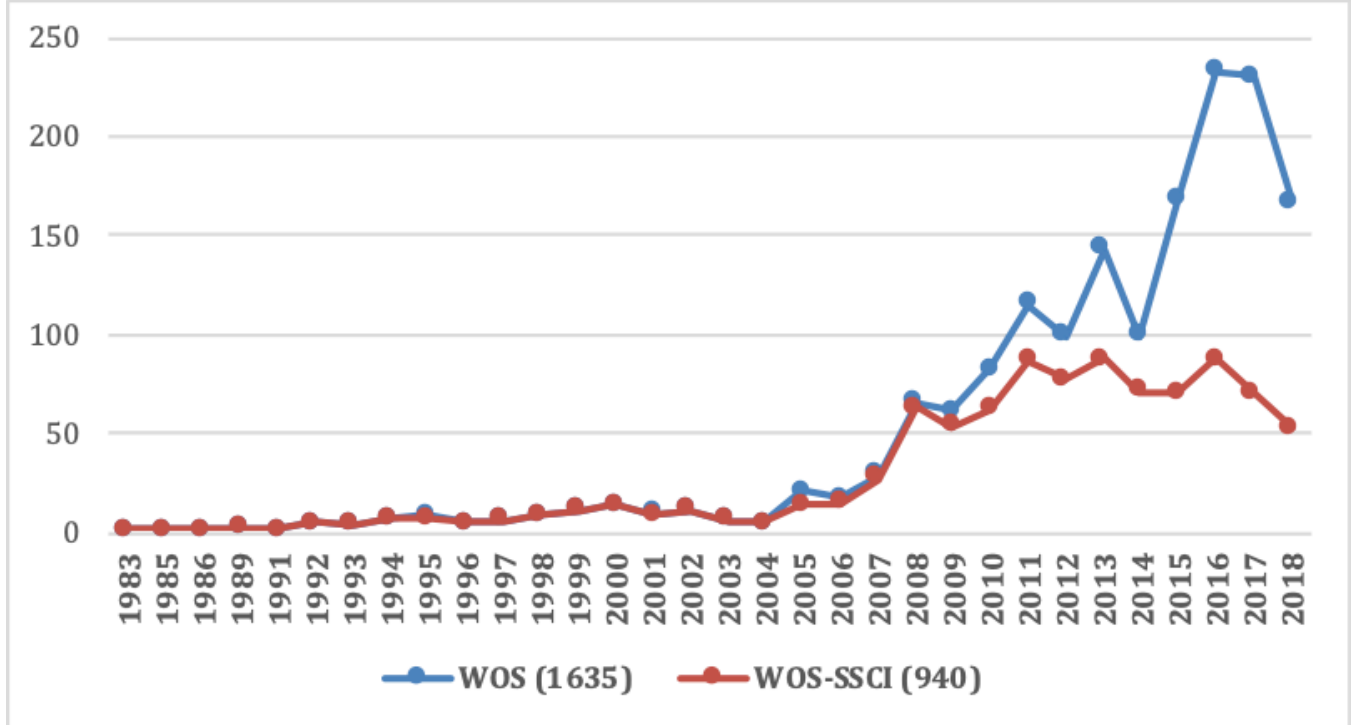

Figure 1. Total number of publications under the topic "Emerging Technologies" (1980-2018) Source: Clarivate Analytics (2018).

The continuous and rapid progress of technology has made the academic and scientific world, especially in the field of education, focus on studying the advantages and disadvantages of the use of ICTs in classrooms, as well as the use of different types of ETs. It is necessary to add, as well, all recommendations and suggestions given by international organizations that have deeply influenced the decision making process of governments regarding education policy. These organizations also assume future projections regarding this issue.

The UNESCO (2015), relying on the essential axes of accessibility, equanimity and inclusion, together with quality and all learning results based on a competency-based learning, determined that there is a need to use the potential of ICTs in order to achieve its objectives by 2030. Mobile learning, open educational resources (OER), the need to provide access to open-access publishing (especially for professionals), and open-source software are highlighted. Regarding lifelong learning, MOOCs have also become one of the key features of a permanent and updated training. As a consequence, all governments have been urged to increase their pedagogical efficiency and to provide accredited certificates. The UNESCO doesn't ignore the emergency of the generated data in the network; that's why it has established learning analytics and data mining as a viable environment that forges the path towards a better understanding of the students' learning process, as well as the possibility to adapt and improve the mentioned learning processes environments, especially those performed online, always respecting the individuals' protection and privacy. Lastly, the importance of accrediting and validating all acquired knowledge, the aptitudes and competences from informal, formal and non-formal educational environments is advocated. In fact, some experiments are being carried out in a higher education environment that are trying to approach this area through blockchains (Pina, Torlà, Quintero, \& Segura, 2017).

According to what has been described, the European Commission (2018) developed the actions to conduct in the Digital Education Action Plan that was initiated in January, where the need to develop blockchains technology was discerned, since it is expected to implement a European common framework for issuing certificates that may be digitally verifiable and accessible anywhere. Following the propositions of UNESCO, programming and robotics were added to the common digital competence framework. For this reason, cyber security and entrepreneurship training have become especially relevant on the way to an open science. Lastly, in 2018, some pilot projects 
about artificial intelligence and learning analytics have been initiated in order to promote a deep and adaptative learning.

Given all this information, it is interesting to look at the vision provided in the last five years Horizon reports in order to present an overview of the trends in educational technology, in both primary and secondary education and higher education. When focusing on primary and secondary education, it can be observed that learning analytics appeared in the 2013, 2014 and 2017 editions (Freeman, Adams Becker, Cummins, Davis, \& Giesinger Hall, 2017; Johnson, Adams Becker, Cummins, Estrada, \& Freeman, 2014; Johnson et al., 2013a), whereas when referring to higher education, this analytics appeared in the last five editions (Adams Becker, Cummins, Freeman, Giesinger Hall, \& Ananthanarayanan, 2017; Johnson et al., 2013b; Johnson, Adams Becker, Estrada, \& Freeman, 2015; Johnson, Adams Becker, Estrada, Freeman, \& Giesinger Hall, 2016; Johnson, Adams Becker, Estrada, \& Freeman, 2014; O'Brien, 2018). Virtual laboratories and makerspaces, as well as hybrid and ubiquitous learning and collaborative environments, appear consecutively since 2013. All perspectives of profound learning are presented in primary and secondary education in the 2014, 2016 and 2017 editions (Adams Becker, Cummins, Freeman, Giesenger Hall, \& Yuhnke, 2016; Freeman et al., 2017; Johnson, Adams Becker, Cummins, et al., 2014). However, these perspectives appear between 2014 and 2017, but they disappear in 2018. Broadly speaking, same thing happens when it comes to the prevalence of adaptative learning environments. The recurring ETs in the last two or three editions at all levels have been robotics, artificial intelligence and mixed reality. Programs such as Bring Your Own Device (BYOD) and Flipped Classroom have become increasingly important during the last five years.

When focusing on learning analytics, it is necessary to clarify that they derive from the concept of Big Data. This concept is based on an enormous quantity of data generated by all Internet users through their performed interactions, as well as the speed in which these data are multiplied, their diversity and their verifiability (Kacfah Emani, Cullot, \& Nicolle, 2015; Philip Chen \& Zhang, 2014; Viberg, Hatakka, Balter, \& Mavroudi, 2018). Therefore, learning analytics have focused on the improvement of the students' learning process (Clow, 2013; Zilvinskis, Willis, \& Borden, 2017), including all data generated by those who are learning or those who work in the educational field (Clow, 2013; Zilvinskis, Willis, \& Borden, 2017). For that matter, research has focused on the students' behavior in online learning environments (Akhtar, Warburton, \& Xu, 2017; Brooks, Greer, \& Gutwin, 2014; Manjarres, Sandoval, \& Suárez, 2018b). On the other hand, learning analytics, which are founded upon a continuous feedback, have become an essential element when designing and developing virtual learning environments in a customizable way. They have also become an essential element when referring to the increasing students' success thanks to the predictive participation model and the students interaction with platforms (Baker \& Inventado, 2014; DietzUhler \& Hurn, 2013; San Pedro, Baker, \& Heffernan, 2017; Xing, Guo, Petakovic, \& Goggins, 2015).

In a study carried out looking at secondary education students, San Pedro, Baker, \& Hefferman (2017) added emotions as variables, as well as previous knowledge and the students' behavior towards the learning environment. This way, they provided an enriched view of what students experiment through their entire academic life and the cognitive and non-cognitive mechanisms that are activated. This allows the teacher to see every student's personal academic trajectory and the way they interact in a higher education environment. Lastly, some studies tried to analyze the use of learning analytics in order to discover elements that affect the learning results of the students through educational games (Hernández-Lara, Perera-Lluna, \& Serradell-López, 2018), by searching for an educational inclusion (Nguyen, Gardner, \& Sheridan, 2018), and by determining the benefits and the inconveniences of its application (Rodriguez Triana, Martínez-Monés, \& Villagrá-Sobrino, 2015). 
If learning analytics have been considered to be a tool to improve the students' learning process, all perspectives of profound learning have become the path to take to achieve a meaningful and lasting learning process, establishing a difference between knowledge comprehension and a simple memorization (Pegrum, Bartle, \& Longnecker, 2015). Some authors concluded that comprehension is an irreversible process within the whole learning process, especially when it's based on peer to peer assessment, on adaptation and its application in real contexts (Biggs \& Tang, 2007). A profound learning process includes a critical analysis of new ideas and concepts, as it is related to previous knowledges and experiences. This helps to connect with other knowledges which can be linked in non-familiar contexts (Houghton, 2004).

Backer, Van Keer, Moerkerke, \& Valcke (2016) studied the peculiarities of metacognitive processes of university students, through collaborative learning, based on peer tutoring. This way, they concluded that the regulation increased, as the research progressed, revealing that, although the main strategies were used at the beginning of the superficial learning (trend that changed when peer tutoring activities began), students went through a profound learning process. In this vein, Howard, Di Eugenio, Jordan, \& Katz (2017) added co-construction of knowledge as a key element for a profound learning process, concluding that the modeling of training software must lead to the reproduction and simulation of peer tutoring activities. On the other hand, Choi, Land, \& Zimmerman (2018) carried out a research after studying a group of 9 to 12 years-old students during a summer camp. Their aim was to design a mobile app that could be used as a data collection tool, where all problem-solving strategies developed by all the students were collected. The results showed that a natural environment helps to develop a profound learning process thanks to the association of ideas, the use of real techniques of problem-solving and the real-time decision-making. The innovative educational trend of Flipped Classrom has also proved to be of great help in the acquisition of meaningful and lasting learning, and collaborative learning. The inverted classroom has proved to encourage a profounder and broader approach to learning by promoting and facilitating the problem-solving strategies, improving the critical thought and teamwork (Baytiyeh \& Naja, 2017; McLean, Attardi, Faden, \& Goldszmidt, 2016).

Up to now, we have seen the relationship between some ET; the same happens with adaptative learning, it is not possible to carry out a split of the above, since the interrelation between them is clear, as well as how they support each other in educational contexts. The studies about adaptative learning are heading towards the study of motivation, preferences, and learning styles, especially of the students. Garcia-Ros \& Perez-Gonzalez (2011) confirm in their research that students who prefer non-conventional training approaches maintain a profound and more elaborated learning style, showing an essential motivation for learning, a high academic self-efficacy and greater appreciation of learning tasks. It should be taken in mind that the adaptative learning programs aim to provide training for students with an appropiate level of difficulty, give feedback and enable mastery of skills before progressing to the next level. The researches conclude that these programs have many benefits for students, with special emphasis on recognition by students of the need to make decisions about which to use and how to integrate them into the classroom (Smith, 2018). Other authors mention adaptative competence, being the ability to apply with flexibility knowledge and skills in different contexts (De Corte, 2015). The creation and design of platforms and tools as a mean to develop an adaptative learning has also proliferated in recent years; these tools are integrated primarily in Moodle as modules based on the construction of the learning itself through the choices of the students, and with the possibility given to teachers to modify the structure of lessons thanks to statistics generated in real time by students (Castellon-Fuentes, MorenteMolinera, Herrera-Viedma, \& Lopez-Herrera, 2013; Giardina, 1998; Zniber, 2011).

Lastly, it has been observed that most studies have attempted to characterize the effects of these innovations on the student body, what benefits and disadvantages has shown their researches, and students' behaviors and attitudes regarding the ET used (Kirkwood \& Price, 2013). Others have 
approached the barriers inherent in the application of ETs to the educational field through the interrelation of the elements that contribute to its construction when the technology is adopted in the classrooms. Its delimitation will allow different educational actors to plan successfully and to include ETs in the curriculum (Rogers, 2000). Finally, we take up the thoughts of Prendes (2018) regarding the promising forward planning of the world of education, but from a responsible approach in the development of theoretical patterns based on the pedagogical practice that finds a support in technologies and leads to a didactic act thought as a mediated process. Therefore, although the repercussion of the subject in the educational field is glimpsed, this study tries to delve into the incorporation of the Emerging Technologies from multiple perspectives.

\section{Methodology}

The methodology of the study is based on the documentary analysis, using documentation as a data gathering method (Sampieri, Collado \& Lucio, 2014). In order to do that, we looked for empiric studies on Emerging Technologies in education. Articles found in databases as the Web of Science and Scopus were considered for the study because they deem tha "the comparative use of databases is a method used in researches that measure the impact of a term or trend" (Aguaded, 2016 , p. 81). The preliminary searching strategy applies the option "topic" in the "Web of Science (WOS)" database, while the Scopus database uses the option "article, title, summary and keyword". The timespan was established from 2013 to 2018* (until October). The total amount of works considered was 62, being the descriptors applied "profound learning, analytics learning, blockchains, measuring learning, adaptative learning y collaborative learning", of which a percentage of the publications on scientific journals indexed in both databases were reiterated. The study was designed following the structure and recommendations of other systematic reviews (Torres-Toukoumidis, Romero-Rodríguez \& Pérez-Rodríguez, 2018; Suárez-Manzano et al., 2018; Manca, 2018) regarding databases, searching strategies, limits and filtered documents presented in table 1.

\begin{tabular}{|c|c|c|}
\hline Databases & Searching strategy & Filtering \\
\hline \multirow{10}{*}{$\begin{array}{l}\text { Web of } \\
\text { Science } \\
\text { (Wos) }\end{array}$} & TOPIC: (PROFOUND AND LEARNING OR ADAPTATIVE AND & \multirow{10}{*}{115} \\
\hline & LEARNING OR BLOCKHAINS OR MEASURING AND & \\
\hline & LEARNING OR COLLABORATIVE AND LEARNING OR & \\
\hline & LEARNING AND ANALYTICS) & \\
\hline & Refined by: RESEARCH DOMAINS: (SOCIAL SCIENCES AND & \\
\hline & EDUCATION SCIENCES) AND DOCUMENT TYPES: (ARTICLE) & \\
\hline & AND Databases: (WOS OR SCIELO) AND LANGUAGES: & \\
\hline & (ENGLISH) AND RESEARCH AREAS: (EDUCATION & \\
\hline & EDUCATIONAL RESEARCH) & \\
\hline & $\begin{array}{l}\text { Timespan: 2013-2018. Databases: WOS, CCC, DIIDW, } \\
\text { KJD, MEDLINE, RSCI, SCIELO. }\end{array}$ & \\
\hline \multirow{3}{*}{ SCOPUS } & $\begin{array}{l}\text { TITLE-ABS-KEY (profound AND learning OR adaptative AND } \\
\text { learning OR blockhains OR measuring AND learning OR } \\
\text { collaborative AND learning OR learning AND analytics) }\end{array}$ & \multirow{3}{*}{27} \\
\hline & AND DOCTYPE ( ar ) AND PUBYEAR $>2013$ AND & \\
\hline & PUBYEAR < 2019 AND ( LIMIT-TO ( SUBJAREA，"SOCI") & \\
\hline
\end{tabular}




\begin{tabular}{|c|c|c|}
\hline & $\begin{array}{l}\text { Inclusion criteria "Social Science" \& "Education Educational } \\
\text { and research" }\end{array}$ & 97 \\
\hline & $\begin{array}{l}\text { Exclusion criteria: repetition, research area, study design } \\
\text { and representation }\end{array}$ & 35 \\
\hline TOTAL & & 62 \\
\hline
\end{tabular}

Table 1. Preliminary analysis of the document search.

Source: own elaboration

\section{a. Procedure}

The general selection criteria refer to articles in peer-reviewed journals with populations regarding educational contexts and quantitative, qualitative or mixed methodological design. The studies coauthorship has been another aspect that has been taken into account regarding the collaboration degree (CD) in each document (Subramanyam, 1983), being the co-autorship of documents the unit of measure at author level. A global value of the CD of 0.96 was obtained during the 20132018 timespan, which indicates a high number of authors within the records selected for the study, similar to the ones in the Web of Science as well as the ones in Scopus (Jiménez-Fanjul, 2016). With regard to data extraction, the number of records in its initial phase was 142, 115 of them were obtained from the Web of Science and 27 from Scopus, 18 of them were repeated and only 9 records appeared in Scopus, filtering a total of 97 records (see table 1). A total of 35 records were excluded, all of them following a filtering procedure regarding repetition (Spikol et al., 2018; McDonald et al., 2017; Pardo et al., 2017; Chen et al., 2017; Bodily et al., 2017; MartínezMaldonado et al., 2015; Haya et al., 2015; Choi et al., 2018), study design (Bayne, 2015; Selwyn, 2015; Spector, 2013; Williamson, 2014; Sobe, 2018; Heerwegh, De Wit, \& Verhoeven, 2016; Shroff, Trent, Ng, 2013; Fu, Hwang, 2018; Anderson et al., 2018; Cerrato-Lara et al., 2017), research area (Durksen et al., 2017; Lloyd, Morris, Portilla, 2014; Triyanto, Handayani, Rifati, 2018; Ruiz-Ariza, 2018; Schaffer, 2017; Hirshfield, 2018) and representation (Neill, DeFranco, Sangwan, 2017; Dorner, 2018; Suryanti, Ibrain, Lede, 2018; Artoni et al., 2018; Garibay, 2018; Phan et al., 2018; Muñoz Repiso et al., 2018; Ruiz-Castillo, 2018; Aguilar, 2018; Le, Janssen \& Wubbels, 2018; Näykki et al.,2017).

\begin{tabular}{|c|}
\hline \begin{tabular}{c} 
Initial searching [2013/2018] \\
\hline "Profound learning", "analytics learning", "blockchains", "measuring", "adaptative \\
learning" "collaborative learning"
\end{tabular} \\
\hline Results found: \\
Wos:115 \\
Scopus: 27 \\
\hline Duplicated 18 \\
\hline Exclusion criteria* 35 \\
Inclusion criteria \\
\hline Articles "Social Sciences", "Education Educational and research \\
n= 97 \\
Final selection \\
\hline Empirical articles that relate profound learning, analytics learning, e-learning, \\
adaptative learning and collaborative learning \\
n= 62
\end{tabular}


Table 2. Process of sample selection Source: own elaboration

*Exclusion criteria: repetition, research area, study design and representation

On the other hand, figure 1 has allowed us to check the evolution of the analyzed studies in the last years, from 2013 to 2018, distributed in the two selected databases.

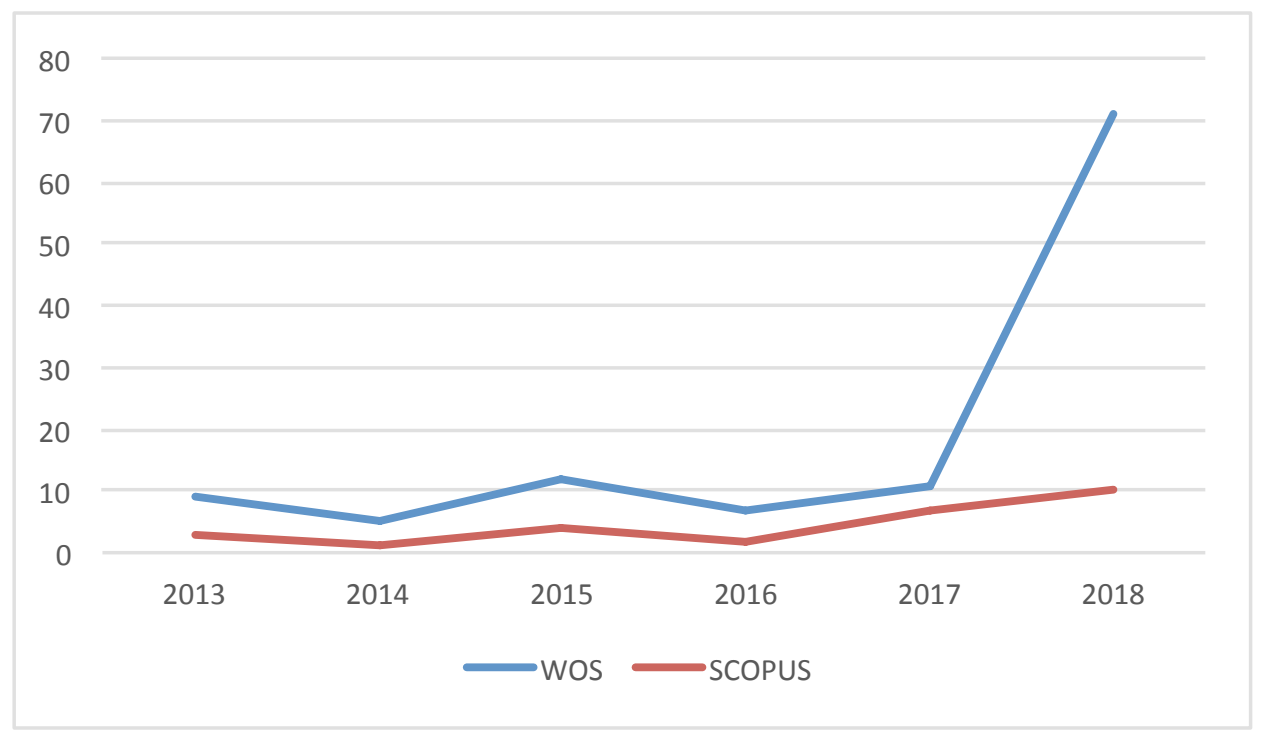

Figure 2. Distribution of the publications from 2013 to 2018

Source: compilation based on data bases above mencioned

The complete articles evaluated for the inclusion in the final review were 62 documents, which constitute the population of the study; once agreed by two external reviewers that confirmed the extraction and final choice based on the inclusion and exclusion criteria (see table 3), which constitutes the first stage of the study. The search intention was focused on researches related to emerging technologies, whose topics responded to collaborative learning, profound learning, adaptative learning, learning analytics and e-learning. The second stage was restricted to the analysis of the theoretical framework, the population, data collection techniques and instruments, analysis and results of the included studies. The third stage consists of analyze the 62 complete articles, once analyzed in the first stage at the level of title, summary and keywords. At this stage, the content of the articles is structured according to the criteria used by Wollscheid et al. (2016) that help us to discuss their content with the theoretical framework of the study. The last stage, bring us closer to get a current non-inclusive image of the results being obtained in the last five years on the effects and consequences of the emerging analytics analyzed.

\begin{tabular}{|c|c|c|c|}
\hline Authors & Population & Instruments & Journal \\
\hline 1. Erhel, \& Jamet (2013) & UE 90 & Q VLE & Computers \& Education \\
\hline $\begin{array}{l}\text { 2. Van Leeuwen, Janssen, } \\
\text { Erkens \& Brekelmans } \\
(2015)\end{array}$ & UE 40 & LAT & Computers \& Education \\
\hline 3. Kizilcec, & UE 4831 & Q & Computers \& Education \\
\hline
\end{tabular}




\begin{tabular}{|c|c|c|c|}
\hline Maldonado (2017) & \multirow[b]{2}{*}{ UE 98} & \multirow[b]{2}{*}{ Q VLE I } & \multirow{2}{*}{ Computers \& Education } \\
\hline 4. Barak \& Asakle (2018) & & & \\
\hline $\begin{array}{l}\text { 5. Filius, Kleijn, Uijl, Prins, } \\
\text { Rijen \& Grobbee (2018) }\end{array}$ & UE 41 & Q VLE I & Computers \& Education \\
\hline 6. Zacharis (2015) & UE 29 & Q VLE & $\begin{array}{l}\text { Internet and Higher } \\
\text { Education }\end{array}$ \\
\hline 7. You (2016) & UE 530 & Q VLE & $\begin{array}{l}\text { Internet and Higher } \\
\text { Education }\end{array}$ \\
\hline $\begin{array}{l}\text { 8. Ognjanovic, Gasevic, \& } \\
\text { Dawson (2016) }\end{array}$ & UE 1061 & $\mathrm{Q}$ & $\begin{array}{l}\text { Internet and Higher } \\
\text { Education }\end{array}$ \\
\hline $\begin{array}{l}\text { 9. Jovanovic, Gasevic, } \\
\text { Dawson, Pardo \& Mirriahi } \\
\text { (2017) }\end{array}$ & UE 290 & Q VLE & $\begin{array}{l}\text { Internet and Higher } \\
\text { Education }\end{array}$ \\
\hline $\begin{array}{l}\text { 10. Akcapinar \& Bayazit } \\
\text { (2018) }\end{array}$ & UE 31 & $\mathrm{Q}$ & $\begin{array}{l}\text { Turkish Online Journal of } \\
\text { Distance } \quad \text { Education- } \\
\text { TOJDE }\end{array}$ \\
\hline $\begin{array}{l}\text { 11. Grover, Pea, \& Cooper } \\
\text { (2015) }\end{array}$ & SE 52 & Q & $\begin{array}{ll}\text { Computer } & \text { Science } \\
\text { Education } & \end{array}$ \\
\hline $\begin{array}{l}\text { 12. Giannakos, } \\
\text { Cuhorianopulos } \\
\text { Chrisochoides (2015) }\end{array}$ & UE 11 & $\mathrm{OQ}$ & $\begin{array}{l}\text { International Review of } \\
\text { Research in Open and } \\
\text { Distributed Learning }\end{array}$ \\
\hline $\begin{array}{l}\text { 13. Aguilar, Cordero \& } \\
\text { Buendia (2017) }\end{array}$ & UE 500 & NA & $\begin{array}{l}\text { Journal of Educational } \\
\text { Computing Research }\end{array}$ \\
\hline $\begin{array}{l}\text { 14. Rau, Bowman \& Moore } \\
\text { (2017) }\end{array}$ & UE 69 & Q & Computers \& Education \\
\hline $\begin{array}{l}\text { 15. Bronnimann, West, Huijser } \\
\text { \& Heath }(2018)\end{array}$ & UE 376 & CS Q I & $\begin{array}{ll}\text { Innovative } & \text { Higher } \\
\text { Education } & \end{array}$ \\
\hline $\begin{array}{l}\text { 16. Gewerc, Montero \& Lama } \\
\text { (2013) }\end{array}$ & UE 58 & CS & Revista Comunicar \\
\hline 17. Lake \& Boyd (2015) & UE 560 & Q & $\begin{array}{l}\text { Australian universities' } \\
\text { review }\end{array}$ \\
\hline $\begin{array}{l}\text { 18. Lai, Hwang, Liang \& Tsai } \\
\text { (2016) }\end{array}$ & UE 1239 & $\mathrm{Q}$ & $\begin{array}{lr}\text { Educational } & \text { Technology } \\
\text { Research } & \text { and } \\
\text { Development } & \end{array}$ \\
\hline $\begin{array}{l}\text { 19. Rubin, Scevak, Southgate, } \\
\text { Macqueen, Williams \& } \\
\text { Douglas (2018) }\end{array}$ & UE 983 & $\mathrm{Q}$ & $\begin{array}{l}\text { Journal of Diversity in } \\
\text { Higher Education }\end{array}$ \\
\hline $\begin{array}{l}\text { 20. Pegrum, Bartle \& } \\
\text { Longnecker (2015) }\end{array}$ & UE 628 & NA Q & $\begin{array}{l}\text { British Journal of } \\
\text { Educational Technology }\end{array}$ \\
\hline $\begin{array}{llr}\text { 21. Gašević, } & \text { Kovanović, } \\
\begin{array}{l}\text { Joksimović } \\
(2014)\end{array} & \text { S } & \text { Siemens }\end{array}$ & UE 28 & NA & $\begin{array}{l}\text { The International Review } \\
\text { of Research in Open and } \\
\text { Distributed Learning }\end{array}$ \\
\hline $\begin{array}{l}\text { 22. Hwang, Hung \& Chen } \\
\text { (2013) }\end{array}$ & PE 167 & $\mathrm{Q}$ & $\begin{array}{lr}\text { Educational } & \text { Technology } \\
\text { Research } & \text { and } \\
\text { Development } & \end{array}$ \\
\hline
\end{tabular}




\begin{tabular}{|c|c|c|c|}
\hline 23. Adams \& Clark (2014) & SE 86 & $\mathrm{Q}$ & Computers \& Education \\
\hline $\begin{array}{l}\text { 24. Vogel, Kurti, Milrad, } \\
\text { Johansson \& Muiller (2014) }\end{array}$ & SE +400 & VLE & $\begin{array}{l}\text { Educational Technology \& } \\
\text { Society }\end{array}$ \\
\hline $\begin{array}{lll}\text { 25. Beausaert, Segers } \quad \& \\
\text { Wiltink (2013) }\end{array}$ & SE 128 & $Q$ & Educational Research \\
\hline $\begin{array}{l}\text { 26. Blasco, Buil, Hernández \& } \\
\text { Sese (2013) }\end{array}$ & UE 198 & Q & Computers \& Education \\
\hline 27. McKenney \& Mor (2015) & SE 34 & I Q CS O NA & $\begin{array}{l}\text { British Journal of } \\
\text { Educational Technology }\end{array}$ \\
\hline 28. Zohar (2013) & PE/SE 8 & I & $\begin{array}{lll}\text { Thinking } & \text { Skills } & \text { and } \\
\text { Creativity } & & \end{array}$ \\
\hline $\begin{array}{l}\text { 29. Sullivan, Gregg, Adams, } \\
\text { Rodgers \& Hull (2013) }\end{array}$ & UE 46 & Q & $\begin{array}{l}\text { Advances in health } \\
\text { sciences education }\end{array}$ \\
\hline 30. Lee, Kang \& Kim (2015) & SE 34 & CS & $\begin{array}{lr}\text { Journal of } & \text { Science } \\
\text { Education } & \text { and } \\
\text { Technology } & \end{array}$ \\
\hline 31. Xiang \& Passmore (2015) & SE 8 & CS & $\begin{array}{l}\text { Journal of science } \\
\text { education and technology }\end{array}$ \\
\hline $\begin{array}{l}\text { 32. Baker, Clarke \& } \\
\text { Ocumpaugh (2016) }\end{array}$ & SE 1579 & VLE & $\begin{array}{l}\text { Journal of computer } \\
\text { assisted learning }\end{array}$ \\
\hline $\begin{array}{l}\text { 33. Baroffio, Vu \& Gerbase } \\
\text { (2013) }\end{array}$ & UE 425 & $\mathrm{Q}$ & $\begin{array}{l}\text { Advances in Health } \\
\text { Sciences Education }\end{array}$ \\
\hline $\begin{array}{l}\text { 34. Evans, Donna, Drape \& } \\
\text { Duke (2014) }\end{array}$ & SE 2 & CS & $\begin{array}{lr}\text { Journal of } & \text { Science } \\
\text { Education } & \text { and } \\
\text { Technology } & \end{array}$ \\
\hline $\begin{array}{l}\text { 35. Hennessy, Haler \& } \\
\text { Hofmann (2016) }\end{array}$ & PE 12 & CS O I DG & $\begin{array}{lll}\text { Research Papers } & \text { in } \\
\text { Education } & & \\
\end{array}$ \\
\hline $\begin{array}{l}\text { 36. Sung, Hwang, Wu \& Lin } \\
\text { (2018) }\end{array}$ & PE 53 & Q & $\begin{array}{ll}\text { Interactive } & \text { Learning } \\
\text { Environments } & \end{array}$ \\
\hline $\begin{array}{l}\text { 37. Junokas, Lindgren, Kang \& } \\
\text { Morphew (2018) }\end{array}$ & UE 21 & Q VLE & $\begin{array}{l}\text { Journal of computer } \\
\text { assisted learning }\end{array}$ \\
\hline $\begin{array}{l}\text { 38. Kucirkova, Messer, } \\
\text { Sheehy \& Fernández (2014) }\end{array}$ & IE 41 & APP & Computers \& Education \\
\hline $\begin{array}{l}\text { 39. Hamilton \& O'Dwyer } \\
\text { (2018) }\end{array}$ & UE 262 & Q I & $\begin{array}{l}\text { Teaching and Teacher } \\
\text { Education }\end{array}$ \\
\hline $\begin{array}{l}\text { 40. Casquero, Ovelar, Romo, } \\
\text { Benito \& Alberdi (2013) }\end{array}$ & UE 121 & VLE & $\begin{array}{ll}\text { Interactive } & \text { Learning } \\
\text { Environments } & \end{array}$ \\
\hline $\begin{array}{l}\text { 41. Fasihuddin, Skinner \& } \\
\text { Athauda (2016) }\end{array}$ & UE 88 & Q & $\begin{array}{l}\text { International Journal of } \\
\text { Learning Technology }\end{array}$ \\
\hline $\begin{array}{l}\text { 42. Ying, Kyungbin \& } \\
\text { LaShaune } \\
\text { (2017) }\end{array}$ & UE 86 & Q & $\begin{array}{l}\text { Journal of Educational } \\
\text { Computing Research }\end{array}$ \\
\hline 43. Er, Kopcha \& Orey (2015) & UE 356 & Q & $\begin{array}{l}\text { Australasian Journal of } \\
\text { Educational Technology }\end{array}$ \\
\hline $\begin{array}{l}\text { 44. Martínez, Torrent \& } \\
\text { González (2018) }\end{array}$ & UE 930 & Q & $\begin{array}{l}\text { Behaviour \& Information } \\
\text { Technology }\end{array}$ \\
\hline
\end{tabular}




\begin{tabular}{|c|c|c|c|}
\hline 45. Lamb (2016) & SE 551 & $\mathrm{Q}$ & $\begin{array}{lr}\text { Journal of } & \text { Science } \\
\text { Education } & \text { and } \\
\text { Technology } & \end{array}$ \\
\hline $\begin{array}{l}\text { 46. Spikol, Ruffaldi, Dabisias \& } \\
\text { Cukurova (2018) }\end{array}$ & UE 18 & VLE & $\begin{array}{l}\text { Journal of Computer } \\
\text { Assisted Learning }\end{array}$ \\
\hline $\begin{array}{l}\text { 47. McDonald, Bird, Zouaq \& } \\
\text { Moskal (2017) }\end{array}$ & UE 110 & $\mathrm{Q}$ & $\begin{array}{l}\text { Journal of Computer } \\
\text { Assisted Learning }\end{array}$ \\
\hline 48. Pardo, Han \& Ellis (2017) & UE 145 & CS Q & $\begin{array}{l}\text { IEEE Transactions on } \\
\text { Learning Technologies }\end{array}$ \\
\hline 49. Chen \& Yeh (2017) & UE 46 & Q & $\begin{array}{l}\text { Educational Technology } \\
\text { and Society }\end{array}$ \\
\hline $\begin{array}{l}\text { 50. Bodily, Nyland \& Wiley } \\
\text { (2017) }\end{array}$ & GN 1002 & CS & $\begin{array}{l}\text { International Review of } \\
\text { Research in Open and } \\
\text { Distance Learning }\end{array}$ \\
\hline $\begin{array}{l}\text { 51. Martínez-Maldonado, Yacef } \\
\text { \& Kay (2015) }\end{array}$ & UE 200 & Q I & $\begin{array}{l}\text { International Journal of } \\
\text { Human Computer Studies }\end{array}$ \\
\hline $\begin{array}{l}\text { 52. Haya, Daems, Malzahn, } \\
\text { Castellanos \& Hoppe (2015) }\end{array}$ & UE 40 & CS & $\begin{array}{l}\text { British Journal of } \\
\text { Educational Technology }\end{array}$ \\
\hline $\begin{array}{l}\text { 53. Choi, Land \& Zimmerman } \\
\text { (2018) }\end{array}$ & PE 25 & APP & $\begin{array}{l}\text { Computers in Human } \\
\text { Behavior }\end{array}$ \\
\hline 54. Xi, Chen \& Wang (2018) & UE- & VLE & $\begin{array}{c}\text { International Journal of } \\
\text { Emerging Technologies in } \\
\text { Learning }\end{array}$ \\
\hline 55. Derr (2017) & UE 603 & Q & $\begin{array}{l}\text { Electronic Journal of } \mathrm{e}- \\
\text { Learning }\end{array}$ \\
\hline $\begin{array}{l}\text { 56. Kelly, } \\
\text { Gonzalez, } \\
\text { Sandoval, Jara, Saurina \& } \\
\text { Alarcón (2017) }\end{array}$ & UE 1467 & CS & $\begin{array}{l}\text { International Journal of } \\
\text { Information and Learning } \\
\text { Technology }\end{array}$ \\
\hline $\begin{array}{l}\text { 57. Kidziński, \& } \begin{array}{l}\text { Giannakos, } \\
\text { Sampson \& Dillenbourg } \\
(2016)\end{array} \\
\end{array}$ & UE 50 & Q LAT & $\begin{array}{l}\text { Lecture Notes in } \\
\text { Educational Technology }\end{array}$ \\
\hline 58. Tochon (2015) & SE 1 & CS & $\begin{array}{l}\text { International Journal of } \\
\text { Pedagogies and Learning }\end{array}$ \\
\hline Dietrichson (2013) & GN 9 & CS DG & $\begin{array}{l}\text { International Journal on } \\
\text { E-Learning: Corporate, } \\
\text { Government, Healthcare, } \\
\text { and Higher Education }\end{array}$ \\
\hline Johri \& Teo (2013) & UE- & I & $\begin{array}{l}\text { Bulletin of the Technical } \\
\text { Committee on Learning } \\
\text { Technology }\end{array}$ \\
\hline $\begin{array}{l}\text { 61. Laakso, kaila \& Rajala. } \\
\text { (2018) }\end{array}$ & GN 4 & VLE & $\begin{array}{lr}\text { Education } & \text { and } \\
\text { Information Technologies }\end{array}$ \\
\hline 62. Nebel, & SE 56 & Q APP & Education \\
\hline
\end{tabular}




\begin{tabular}{|l|l|l|l|}
\hline $\begin{array}{l}\text { Beege, kolda, Mackiewicz \& } \\
\text { Rey (2017) }\end{array}$ & & & Information Technologies \\
\hline
\end{tabular}

Table 3. List of evaluated articles in the final review

Source: own elaboration

* IE: infant education, PE: primary education; SE: secondary education; UE: university education; GN: general

** CS: case studies, I: interview, O: observation; Q: questionnaire; NA: narrative analysis; LAT: learning analytic tools; VLE: virtual learning environment; APP: software app

Regarding the documentary analysis, the procedure developed was based on four different criteria: public, topic, methodological design and main conclusions (Wollscheid, Sjaastad \& Tømte, 2016) that facilitate the categorizing and summary of the information gathered of "profound learning, analytics learning, e-learning, measuring learning, adaptative learning and collaborative learning" in the Web of Science and Scopus, establishing the following subcategories:

- Public: infant education, primary education, secondary education, university education and general.

- Topic: collaborative learning, learning analytics, profound learning, adaptative learning and e-learning.

- Methodological design: empirical with qualitative techniques, empirical with quantitative techniques, empirical with mixed techniques.

- Main conclusions: effects and consequences of the outcomes (learning achievements, design of resources, learning outcomes, implementation of ICT in real-life contexts, teacher professional performance and performance assessment).

\section{Results}

An in-depth analysis of all the studies showed that all of them are referred to emerging technologies in education (100\%), 29 of them focus on collaborative learning; 23 studies whose objective is the learning analytics; 15 of them were about profound learning; 10 of them refer to the adaptative learning and 13 studies are focused on the study of the e-learning, finding studies that address various types of learning. In all the studies, the techniques and instruments used applied a quantitative, qualitative or mixed research methodology, being the questionnaire the most used instrument (38 studies), followed by case studies (19 studies) and the narrative analysis (9 studies), as well as studies referring to virtual learning environments (12 studies) and MOOC. Regarding the degree of co-authorship, 56 of the studies had between 2 and 8 authors, and only 6 studies were conducted by just one author. This review includes data from, approximately, 20,957 individuals, with studies' size samples that varies from 1 to 4,831 participants depending on whether the design was quantitative, qualitative or mixed, being two studies that did not require the sample in the document. The analyzed studies were entirely in English. The results from the documentary analysis are structured around the following criteria:

\section{a. Public}

Among the reviewed publications, $67.7 \%$ of them used research samples referred to primary education students, followed by higher education students $(17.7 \%)$. On the other hand, $6.5 \%$ of the publications are of general nature; $6.5 \%$ are addressed to primary education and $1.6 \%$ of 
them are infant education oriented (Table 4). On the other hand, the size of the samples is remarkably variable; this means that there is no common magnitude for sampling between different studies. Besides, university studies developed in virtual learning environments (4 studies), together with those developed in secondary education ( 2 studies), stand out.

\begin{tabular}{|c|c|}
\hline Public & Publications \\
\hline Infant education & Kucirkova, Messer, Sheehy \& Fernández (2014) \\
\hline Primary education & $\begin{array}{l}\text { Hwang, Hung \& Chen (2013); Hennessy, Haler \& Hofmann } \\
\text { (2016); Sung, Hwang, Wu \& Lin (2018); Choi, Land \& } \\
\text { Zimmerman (2018). }\end{array}$ \\
\hline Secondary education & $\begin{array}{l}\text { Grover, Pea \& Cooper (2015); Adams \& Clark (2014); } \\
\text { Vogel, Kurti, Milrad, Johansson \& Muller (2014); } \\
\text { Beausaert, Segers \& Wiltink (2013); McKenney \& Mor } \\
\text { (2015); Xiang \& Passmore (2015); Baker, Clarke \& } \\
\text { Ocumpaugh (2016); Evans, Donna, Drape \& Duke (2014); } \\
\text { Lamb (2016); Tochon (2015); Nebel, Schneider, Beege, } \\
\text { kolda, Mackiewicz \& Rey (2017). }\end{array}$ \\
\hline University education & $\begin{array}{l}\text { Erhel \& Jamet (2013); Van Leeuwen, Janssen, Erkens \& } \\
\text { Brekelmans (2015); Kizilcec, Perez \& Maldonado (2017); } \\
\text { Barak \& Asakle (2018); Filius, Kleijn, Uijl, Prins, Rijen \& } \\
\text { Grobbee (2018); Zacharis (2015); You (2016); Ognjanovic, } \\
\text { Gasevic \& Dawson (2016); Jovanovic, Gasevic, Dawson, } \\
\text { Pardo \& Mirriahi (2017); Akcapinar \& Bayazit (2018); } \\
\text { Giannakos, Cuhorianopulos \& Chrisochoides (2015); } \\
\text { Aguilar, Cordero \& Buendia (2017); Rau, Bowman \& Moore } \\
\text { (2017); Bronnimann, West, Huijser \& Heath (2018); } \\
\text { Gewerc, Montero \& Lama (2013); Lake \& Boyd (2015); } \\
\text { Lai, Hwang, Liang \& Tsai (2016); Rubin, Scevak, } \\
\text { Southgate, Macqueen, Williams \& Douglas (2018); } \\
\text { Pegrum, Bartle \& Longnecker (2015); Gašević, Kovanović, } \\
\text { Joksimović \& Siemens (2014); Blasco, Buil, Hernández \& } \\
\text { Sese (2013); Sullivan, Gregg, Adams, Rodgers \& Hull } \\
\text { (2013); Lee, Kang \& Kim (2015); Baroffio, Vu, \& Gerbase } \\
\text { (2013); Junokas, Lindgren, Kang \& Morphew (2018); } \\
\text { Hamilton \& O'Dwyer (2018); Casquero, Ovelar, Romo, } \\
\text { Benito \& Alberdi (2013); Fasihuddin, Skinner \& Athauda } \\
\text { (2016); Ying, Kyungbin \& LaShaune (2017); Er, Kopcha \& } \\
\text { Orey (2015); Martínez, Torrent \& González (2018); Spikol, } \\
\text { Ruffaldi, Dabisias \& Cukurova (2018); McDonald, Bird, } \\
\text { Zouaq \& Moskal (2017); Pardo, Han \& Ellis (2017); Chen \& } \\
\text { Yeh (2017); Martínez-Maldonado, Yacef \& Kay (2015); } \\
\text { Haya, Daems, Malzahn, Castellanos \& Hoppe (2015); Xi, } \\
\text { Chen \& Wang (2018); Derr (2017); Kelly, Montenegro, } \\
\text { Gonzalez, Clasing, Sandoval, Jara, Saurina \& Alarcón } \\
\text { (2017); Kidziński, Giannakos, Sampson \& Dillenbourg } \\
\text { (2016); Johri \& Teo (2013). }\end{array}$ \\
\hline
\end{tabular}




\section{General}

Table 4. Distribution of publications according to the public

Source: own elaboration

\section{b. Topic}

Regarding keywords and general objectives (table 5), 32\% of the articles refer to collaborative learning. $25 \%$ of them deal with studies that incorporate learning analytics, along with a $17 \%$ of the studies on profound learning. On the other hand, $12 \%$ of the studies are focused on adaptative learning. Finally, $14 \%$ of the documents analyzed refer to e-learning (Table 4). In addition, there are studies that include several of the mentioned topics, as in the case of collaborative learning and learning analytics, which appear together in six documents; other six studies apply learning analytics and e-learning; profound learning and collaborative learning appear combined in seven of the studies; adaptative learning and collaborative learning are applied in four documents and two of the articles combine adaptative learning and e-learning.

Regarding collaborative learning, Gewerc, Montero and Lamas (2014), apply collaborative learning with learning analytics using two types of techniques: social media analysis and extraction of information, highlighting the intensity, centrality and relevance of the the collaboration between students. This way, the collaborative environments are not generated by the existence of specific software, as they require approaches and proposals to mobilize, support and improve collaboration, reaching a high level of interaction, in line with Van leeuwen, Janssen et al. (2015). The study of Rau, Bowman \& Moore (2017) raises the question on how the representation of an adaptative collaboration script can improve profound learning. Hwang, Hung and Chen (2013) introduce games in collaboration, in addition to the advice among peers as an alternative way of promoting interactions between partners and the improvement of profound learning. In their study, Hennessy, Haler and Hofmann (2016) come to consider the global perspective, supporting the collaboration efforts between participants, keeping them in touch with the world, while encouraging their own personal interests and growing their intrinsic motivations. The study developed by Casquero, Ovelar, et al. (2013), showed the potential of PLEs (Personal Learning Environment) over VLEs (Virtual Learning Environment) to the extent that participation and interaction are the basis to develop a set of competences, as collaboration, teamwork or organization of self-learning. The studies of Martínez, Torrent and González (2018), analyze how the development of collaborative abilities are encouraged, through nine information and communication tools (ICT) related with gamification and the use of virtual reality and social media.

Many authors have studied the learning analytics topic combining data with learning objects (Spikol et al., 2018), learning abilities (Pardo, Han, \& Ellis, 2017), retention (Choi, Land \& Zimmerman (2018), or aggregated evaluation resources (Bodily, Nyland \& Wiley, 2017), in the attempt to find deeper patterns and to provide more precise predictions of the behaviors and results of students (Kidziński et al., 2016). The study of Gewerc, Montero and Lamas (2014), highlights the utility of learning analytics techniques to drive the teacher's decision making process. Johri and Teo (2013), consider data analysis to examine informal learning in online communities and demonstrate the viability.

Profound learning is projected in the investigations, relating the factors that affect that learning. The feedback in the training process, as well as the feedback peer-to-peer mediated by the conversation generated, promote profound learning in the SPOC. The question is not to emphasize the feedback itself, but the conversation space generated, allowing developing processes of thinking and critical ability (Filius, Klejin et al., 2018). Furthermore, it is suggested that the tendency to change from a superficial learning to a profound learning is more related with other 
factors than with age itself. It is highlighted that people with an early school drop-out do not show significant differences regarding a change from superficial to profound learning, in comparison with students that have had a progressive and complete academic life (Lake \& Boyd, 2015). On the other hand, there are gender differences, being women those who develop a deep and bigger learning, and it is also related with a high degree of satisfaction with the studied degree (Rubin et al., 2018). It stands out that an approach focused on the teacher predicts the student superficial learning, on the contrary, when the approach is centered on students, the tendency changes towards the development of a profound learning. In order for the students to develop a profound learning, centers must pay attention to the approach that the teachers develop in their teaching practice (Beausaert, Segers \& Wiltink, 2013). The individual learning approaches bring a synergic effect to group modelling processes, encouraging profound learning, which, at the same time, drives the establishment of general guidelines for teachers who want to carry out collaborative strategies (Lee, Kang \& Kim, 2015). The study of Akcapinar and Bayazit (2018) compares students' behavior regarding video viewing. Students with superficial learning approaches interacted less with audiovisual material (pause, play, rewind or fast forward the video) than those who developed superior mental operations (metacognition/profound learning), who maintained a less linear behavior. These beahvioral patterns may help to improve material, both in quality and efficiency. Learning approaches between first-time admitted students and those who have been in the institution for some time are different, the elements that influence this aspect are their motivation to learn, the collaborative learning, previous education experiences and school organization (Hamilton \& O'Dwyer, 2018). Spikol et al. (2018), present in their study how emerging computer techniques can be used to generate information on the students' profound learning. The profound learning techniques or strategies are more promising than the traditional ones, especially in artificial intelligence environments (machine learning).

Regarding adaptative learning, Derr (2017) develops a customized behavior analysis model of adaptative learning and designs a customized MOOC platform based on the model. The model goes further in learning behaviors and reveals the relation between learning behaviors and implicit data to understand the essence of the learning process and implement a customized teaching. In that way, the study of Fasihuddin, Skinner and Athauda (2016) presents an adaptative framework to customize open learning environments. Tochon's (2015) study presents how the mobile content program must be faithful to the creation of constructive, adaptable and creative resources to perform autodetermined projects. The study of Hwang, Hung and Chen (2013) states that, in order to provide an effective learning environment based on digital games, it is important to design good strategies; and, in addition, the learning objectives and contents must be well integrated. In the same line, Kucirkova et al. (2014), in their study make reference to characteristics and how the content of the application can influence the children's commitment. The more the application supports open content achievements, the bigger will be the probability that the activity have positive educational impact.

Lastly, e-learning is projected from the works developed by Xi, Chen and Wang (2018). The authors develop a customized behavior analysis model of adaptative learning and design a customized MOOC platform based on the model. The model goes further in learning behaviors and reveals the relation between learning behaviors and implicit data to understand the essence of the learning process and implement a customized teaching. In the same line appears the study developed by Fasihuddin, Skinner and Athauda (2016) on the adaptative framework to customize open learning environments. The studies developed by Akcapinar and Bayazit (2018), and Giannakos, Cuhorianopulos and Chrisochoides (2015), propose the analysis of the learning approaches in video viewing and the analysis of open access video for its use in a video-assisted course, respectively. The studies analyzed with regard to MOOCs, raise the question, on the basis of the work of Johri and Teo (2013), of how MOOCs are compatible with discussion forums to encourage the collaboration and exchange of knowledge between students and with instructors. In addition, the 
study of Kizilcec, Perez and Maldonado (2017), quantifies the benefits of the MOOCs regarding the different learning strategies, identifies the behavioral manifestation of the different strategies and exposes individual differences. Gašević et al. (2014) propose the analysis of research proposals presented through MOOCs. The work of Haya et al. (2015) is based on the preparation and motivation of students to achieve their future commitment to solve problems of algorithms through the MOOCs. On the other hand, the study of Kelly et al. (2017) establishes the qualifications of the students in relation with the qualifications of the MOOCs, as a decisive factor for the inscription in future course selections.

\begin{tabular}{|c|c|}
\hline Topic & Publications \\
\hline CL: Collaborative learning & $\begin{array}{l}\text { Derr (2017); Nebel, Schneider, Beege, kolda, Mackiewicz } \\
\text { \& Rey (2017); Lai, Hwang, Liang \& Tsai (2016); Vogel, } \\
\text { Kurti, Milrad, Johansson \& Muiller (2014); Blasco, Buil, } \\
\text { Hernández\& Sese (2013); Xiang \& Passmore (2015); Ying, } \\
\text { Kyungbin \& LaShaune (2017); Er, Kopcha \& Orey (2015); } \\
\text { Er, Kopcha \& Orey (2015); Chen \& Yeh (2017); Martínez- } \\
\text { Maldonado, Yacef \& Kay (2015); Choi, Land \& Zimmerman } \\
\text { (2018); Laakso, kaila \& Rajala (2018); Van Leeuwen, } \\
\text { Janssen, Erkens \& Brekelmans (2015); Jovanovic, Gasevic, } \\
\text { Dawson, Pardo \& Mirriahi (2017); Gewerc, Montero \& } \\
\text { Lama (2013); Casquero, Ovelar, Romo, Benito \& Alberdi } \\
\text { (2013); Haya, Daems, Malzahn, Castellanos \& Hoppe } \\
\text { (2015); Rau, Bowman \& Moore (2017); Hwang, Hung \& } \\
\text { Chen (2013); Adams \& Clark (2014); Kucirkova, Messer, } \\
\text { Sheehy \& Fernández (2014); Pegrum, Bartle \& Longnecker } \\
\text { (2015); Lee, Kang \& Kim (2015); Baroffio, Vu, \& Gerbase } \\
\text { (2013); Evans, Donna, Drape \& Duke (2014); Hennessy, } \\
\text { Haler, \& Hofmann (2016); Sung, Hwang, Wu \& Lin (2018); } \\
\text { Lamb (2016). }\end{array}$ \\
\hline LA: Learning analytics & $\begin{array}{l}\text { Kelly, Montenegro, Gonzalez, Clasing, Sandoval, Jara, } \\
\text { Saurina \& Alarcón (2017); Zacharis (2015); Aguilar, } \\
\text { Cordero \& Buendia (2017); Bronnimann, West, Huijser \& } \\
\text { Heath (2018); McKenney \& Mor (2015); Baker, Clarke \& } \\
\text { Ocumpaugh (2016); Junokas, Lindgren, Kang \& Morphew } \\
\text { (2018); Pardo, Han \& Ellis (2017); Bodily, Nyland \& Wiley } \\
\text { (2017); Laakso, kaila \& Rajala (2018); Van Leeuwen, } \\
\text { Janssen, Erkens \& Brekelmans (2015); Jovanovic, Gasevic, } \\
\text { Dawson, Pardo \& Mirriahi (2017); Gewerc, Montero \& } \\
\text { Lama (2013); Casquero, Ovelar, Romo, Benito \& Alberdi } \\
\text { (2013); Haya, Daems, Malzahn, Castellano \& Hoppe } \\
\text { (2015); Kidziński, Giannakos, Sampson \& Dillenbourg } \\
\text { (2016); Johri \& Teo (2013); Kizilcec, Perez \& Maldonado } \\
\text { (2017); You (2016); Ognjanovic, Gasevic \& Dawson } \\
\text { (2016); Giannakos, Cuhorianopulos \& Chrisochoides } \\
\text { (2015); Akcapinar \& Bayazit (2018); Spikol, Ruffaldi, } \\
\text { Dabisias \& Cukurova (2018). }\end{array}$ \\
\hline PL: Profound learning & $\begin{array}{l}\text { Lake \& Boyd (2015); Rubin, Scevak, Southgate, } \\
\text { Macqueen, Williams \& Douglas (2018); Beausaert, Segers, }\end{array}$ \\
\hline
\end{tabular}




\begin{tabular}{|c|c|}
\hline & $\begin{array}{l}\text { \& Wiltink (2013); Zohar (2013); Sullivan, Gregg, Adams, } \\
\text { Rodgers \& Hull (2013); Hamilton \& O'Dwyer (2018); Filius, } \\
\text { Kleijn, Uijl, Prins, Rijen \& Grobbee (2018); Akcapinar \& } \\
\text { Bayazit (2018); Spikol, Ruffaldi, Dabisias \& Cukurova } \\
\text { (2018); Pegrum, Bartle \& Longnecker (2015); Lee, Kang \& } \\
\text { Kim (2015); Baroffio, Vu \& Gerbase (2013); Evans, } \\
\text { Donna, Drape \& Duke (2014); Hennessy, Haler \& Hofmann } \\
\text { (2016); Sung, Hwang, Wu \& Lin (2018); Lamb (2016); } \\
\text { Sullivan, Gregg, Adams, Rodgers \& Hull (2013). }\end{array}$ \\
\hline AL: Adaptative learning & $\begin{array}{l}\text { Tochon (2015); Dietrichson (2013); Erhel \& Jamet (2013); } \\
\text { McDonald, Bird, Zouaq \& Moskal (2017); Xi, Chen \& Wang } \\
\text { (2018); Fasihuddin, Skinner \& Athauda (2016); Rau, } \\
\text { Bowman \& Moore (2017); Hwang, Hung \& Chen (2013); } \\
\text { Adams \& Clark (2014); Kucirkova, Messer, Sheehy \& } \\
\text { Fernández (2014). }\end{array}$ \\
\hline EL: e-learning & $\begin{array}{l}\text { Barak \& Asakle (2018); Grover, Pea \& Cooper (2015); } \\
\text { Gašević, Kovanović, Joksimović \& Siemens (2014); } \\
\text { Kidziński, Giannakos, Sampson \& Dillenbourg (2016); Johri } \\
\text { \& Teo (2013); Kizilcec, Perez \& Maldonado (2017); You } \\
\text { (2016); Ognjanovic, Gasevic \& Dawson (2016); } \\
\text { Giannakos, Cuhorianopulos \& Chrisochoides (2015); Filius, } \\
\text { Kleijn, Uijl, Prins, Rijen \& Grobbee (2018); Akcapinar \& } \\
\text { Bayazit (2018); Xi, Chen\& Wang (2018); Fasihuddin } \\
\text { Skinner \& Athauda (2016). }\end{array}$ \\
\hline
\end{tabular}

Table 5. Distribution of publications according to the topic

Source: own elaboration

\section{c. Methodological design}

Regarding the methodological design (table 6), the most used systematic process is the substantiation through empirical studies with quantitative techniques $(50 \%)$, followed bymixed studies $(32.3 \%)$, together with qualitative studies (17.7\%), as it can be observed in table 5 . In the same way, the tools used on empirical studies are surveys and questionnaires, in $85 \%$ of the cases. To a lesser extent, appears the interview, the observation and the narrative analysis. The 13 case studies use qualitative instruments, and some studies had reduced samples. In the case of extensive samples, there are 39 studies analyzed (62\%) that used quantitative instruments in general, as the questionnaire.

\begin{tabular}{|l|l|}
\hline \multicolumn{1}{|c|}{ Methodological design } & \multicolumn{1}{|c|}{ Publications } \\
\hline $\begin{array}{l}\text { Empirical with qualitative } \\
\text { techniques }\end{array}$ & $\begin{array}{l}\text { Tochon (2015); Johri \& Teo (2013); Nebel, Schneider, } \\
\text { Beege, kolda, Mackiewicz \& Rey (2017); Aguilar, Cordero, } \\
\text { \& Buendia (2017); Bronnimann, West, Huijser \& Heath } \\
\text { (2018); Gewerc, Montero \& Lama (2013); Zohar (2013); } \\
\text { Evans, Donna, Drape \& Duke (2014); Hennessy, Haler \& } \\
\text { Hofmann (2016); McDonald, Bird, Zouaq \& Moskal } \\
\text { (2017); Choi, Land \& Zimmerman (2018). }\end{array}$ \\
\hline $\begin{array}{l}\text { Empirical with } \\
\text { quantitative techniques }\end{array}$ & $\begin{array}{l}\text { Erhel \& Jamet (2013); Van Leeuwen, Janssen, Erkens \& } \\
\text { Brekelmans (2015); Kizilcec, Perez \& Maldonado (2017); }\end{array}$ \\
\hline
\end{tabular}




\begin{tabular}{|l|l|}
\hline Zacharis (2015); You (2016); Ognjanovic, Gasevic \& \\
Dawson (2016); Akcapinar \& Bayazit (2018); Giannakos, \\
Cuhorianopulos \& Chrisochoides (2015); Rau, Bowman \& \\
Moore (2017); Lake \& Boyd (2015); Lai, Hwang, Liang \& \\
Tsai (2016); Rubin, Scevak, Southgate, Macqueen, \\
Williams \& Douglas (2018); Pegrum, Bartle \& Longnecker \\
(2015); Hwang, Hung \& Chen (2013); Adams \& Clark \\
(2014); Beausaert, Segers \& Wiltink (2013); Blasco, Buil, \\
Hernández \& Sese (2013); Sullivan, Gregg, Adams, \\
Rodgers \& Hull (2013); Baroffio, Vu \& Gerbase (2013); \\
Sung, Hwang, Wu \& Lin (2018); Fasihuddin, Skinner \& \\
Athauda (2016); Ying, Kyungbin \& LaShaune (2017); Er, \\
Kopcha \& Orey (2015); Martínez, Torrent \& González \\
(2018); Lamb (2016); Spikol, Ruffaldi, Dabisias \& \\
Cukurova (2018); Xi, Chen \& Wang (2018); Derr (2017); \\
Kelly, Montenegro, Gonzalez, Clasing, Sandoval, Jara, \\
Saurina \& Alarcón (2017); Kidziński, Giannakos, Sampson \\
\& Dillenbourg (2016); Laakso, kaila \& Rajala (2018). \\
\hline Barak \& Asakle (2018); Filius, Kleijn, Uijl, Prins, Rijen \& \\
Grobbee (2018); Jovanovic, Gasevic, Dawson, Pardo \& \\
Mirriahi (2017); Grover, Pea \& Cooper (2015); Gašević, \\
Kovanović, Joksimović \& Siemens (2014); Vogel, Kurti, \\
techniques \\
Milrad, Johansson \& Muiller (2014); McKenney \& Mor \\
(2015); Lee, Kang \& Kim (2015); Xiang \& Passmore \\
(2015); Baker, Clarke \& Ocumpaugh (2016); Junokas, \\
Lindgren, Kang \& Morphew (2018); Kucirkova, Messer, \\
Sheehy \& Fernández (2014); Hamilton \& O'Dwyer (2018); \\
Casquero, Ovelar, Romo, Benito \& Alberdi (2013); Pardo, \\
Han \& Ellis (2017); Chen \& Yeh (2017); Bodily, Nyland \& \\
Wiley (2017); Martínez-Maldonado, Yacef \& Kay (2015); \\
Haya, Daems, Malzahn, Castellanos \& Hoppe (2015); \\
Dietrichson (2013).
\end{tabular}

Table 6. Distribution of publications according to their methodological design.

Source: own elaboration

\section{d. Main conclusions}

The last criteria (table 7) allows us to value the contributions of every selected investigation. In this way, they are considered as relevant contributions in terms of learning outcomes $(48.2 \%)$; research on the improvement of learning and performance through digital educational games together with peer-to-peer feedback; the development of collaborative skills through gamification, virtual reality and social media; the improvement of online (adaptative) learning environments supporting communication; academic performance expectations and help for students; the use of methodologies to improve learning (flipped learning, PBL, PLE, m-learning, podcasting); research on STEM promoting interest, motivation and curiosity for profound learning; as well as research that guides teacher decision-making and self-regulation of student learning. In terms of learning achievements $(30.3 \%)$, contributions related to self-regulated learning and development of higher order thinking through OER, PLE, m-learning and gamification are proposed. Conclusions of research related to the implementation of ICT in real-life contexts $(6.3 \%)$, the use of mobile 
applications, interactive tables (tabletops) and the analysis of the data generated in them allow to determine the degree of collaboration and commitment by the students, in addition to their decision making in real time. Within the teacher professional performance $(6.3 \%)$, the increase in teacher confidence through the use of learning analytics stands out. Likewise, the importance of reshaping the initial teacher training to teach in an intelligent, flexible and creative way through active and constructivist approaches is emphasized. Regarding the performance assessment $(5.1 \%)$, it stands out that learning analytics can help higher education institutions improve their support resources and career guidance. On the other hand, regarding the evaluation approaches, it is proved that the traditional approaches make the students forget more than half of the basic content of the subjects, while the approaches linked to assessing the significance of learning have a positive impact on the development of the students metacognitive activities and therefore on their academic performance. In relation to the design of resources $(3.8 \%)$, research emphasizes the assessment of student behavior patterns to implement custom learning models in virtual environments.

\begin{tabular}{|l|l|}
\hline Conclusions & \multicolumn{1}{|c|}{ Publications } \\
\hline Learning achievements & Xi, Chen \& Wang (2018); Kelly, Montenegro, Gonzalez, \\
Clasing, Sandoval, Jara, Saurina \& Alarcón (2017); \\
Kidziński, Giannakos, Sampson \& Dillenbourg (2016); \\
Dietrichson (2013); Laakso, kaila \& Rajala (2018); Erhel \& \\
Jamet (2013); Kizilcec, Perez \& Maldonado (2017); Barak \& \\
Asakle (2018); Akcapinar \& Bayazit (2018); Grover, Pea \& \\
Cooper (2015); Aguilar, Cordero \& Buendia (2017); Lai, \\
Hwang, Liang \& Tsai (2016); Vogel, Kurti, Milrad, Johansson \\
\& Muller (2014); Xiang \& Passmore (2015); Hennessy, \\
Haler \& Hofmann (2016); Junokas, Lindgren, Kang \& \\
Morphew (2018); Casquero, Ovelar, Romo, Benito \& Alberdi \\
(2013); Martínez, Torrent \& González (2018); Lamb \\
(2016); Pardo, Han \& Ellis (2017); Chen \& Yeh (2017); \\
Bodily, Nyland \& Wiley (2017); Martínez-Maldonado, Yacef \\
\& Kay (2015); Haya, Daems, Malzahn, Castellanos \& Hoppe \\
(2015). \\
\hline Xi, Chen \& Wang (2018); Fasihuddin, Skinner \& Athauda \\
(2016); Er, Kopcha \& Orey (2015). \\
\hline Derr (2017); Kelly, Montenegro, Gonzalez, Clasing, \\
Sandoval, Jara, Saurina \& Alarcón (2017); Kidziński, \\
Giannakos, Sampson \& Dillenbourg (2016); Johri \& Teo \\
(2013); Laakso, kaila \& Rajala (2018); Nebel, Schneider, \\
Beege, kolda, Mackiewicz \& Rey (2017); Erhel \& Jamet \\
(2013); Kizilcec, Perez \& Maldonado (2017); Filius, Kleijn, \\
Uijl, Prins, Rijen \& Grobbee (2018); Zacharis (2015); You \\
(2016); Jovanovic, Gasevic, Dawson, Pardo \& Mirriahi \\
(2017); Akcapinar \& Bayazit (2018); Grover, Pea \& Cooper \\
(2015); Giannakos, Cuhorianopulos \& Chrisochoides \\
(2015); Rau, Bowman \& Moore (2017); Bronnimann, West, \\
Huijser \& Heath (2018); Gewerc, Montero \& Lama (2013); \\
Lake \& Boyd (2015); Rubin, Scevak, Southgate, Macqueen, \\
Williams \& Douglas (2018); Pegrum, Bartle \& Longnecker \\
\hline
\end{tabular}




\begin{tabular}{|c|c|}
\hline & $\begin{array}{l}\text { (2015); Gašević, Kovanović, Joksimović \& Siemens (2014); } \\
\text { Hwang, Hung \& Chen (2013); Adams \& Clark (2014); } \\
\text { Blasco, Buil, Hernández \& Sese (2013); Baroffio, Vu \& } \\
\text { Gerbase, (2013); Evans, Donna, Drape \& Duke (2014); } \\
\text { Sung, Hwang, Wu \& Lin (2018); Hamilton \& O'Dwyer } \\
\text { (2018); Fasihuddin, Skinner \& Athauda (2016); Ying, } \\
\text { Kyungbin \& LaShaune (2017); Er, Kopcha \& Orey (2015); } \\
\text { Martínez, Torrent \& González (2018); Lamb (2016); Spikol, } \\
\text { Ruffaldi, Dabisias \& Cukurova (2018); McDonald, Bird, } \\
\text { Zouaq \& Moskal (2017); Pardo, Han \& Ellis (2017); Choi, } \\
\text { Land \& Zimmerman (2018). }\end{array}$ \\
\hline $\begin{array}{l}\text { Implementation of ICT in } \\
\text { real-life contexts }\end{array}$ & $\begin{array}{l}\text { Tochon (2015); Nebel, Schneider, Beege, kolda, Mackiewicz } \\
\text { \& Rey (2017); Kucirkova, Messer, Sheehy \& Fernández } \\
\text { (2014); Martínez-Maldonado, Yacef \& Kay (2015); Choi, } \\
\text { Land \& Zimmerman (2018). }\end{array}$ \\
\hline $\begin{array}{l}\text { Teacher professional } \\
\text { performance }\end{array}$ & $\begin{array}{l}\text { Van Leeuwen, Janssen, Erkens \& Brekelmans (2015); Lai, } \\
\text { Hwang, Liang \& Tsai (2016); Beausaert, Segers \& Wiltink } \\
\text { (2013); McKenney \& Mor (2015); Zohar (2013). }\end{array}$ \\
\hline Performance assessment & $\begin{array}{l}\text { Ognjanovic, Gasevic \& Dawson (2016); Sullivan, Gregg, } \\
\text { Adams, Rodgers \& Hull (2013); Lee, Kang \& Kim (2015); } \\
\text { Baker, Clarke \& Ocumpaugh (2016). }\end{array}$ \\
\hline
\end{tabular}

Table 7. Distribution of publications according to the main conclusions.

Source: own elaboration

\section{Discussion and conclusions}

This research has aimed to provide a current state of the art of a dynamic and developing topic, the scientific production on emerging technologies (collaborative learning, profound learning, adaptative learning, learning analytics, e-learning) in two databases (Web of Science and Scopus), together with the challenge of assuming that some works may become obsolete when the study is published or revised, and so it could serve as a reference for future studies and research.

A total of 62 articles from scientific journals from Scopus and Web of Science were analyzed. This review reflects the current panorama (from 2013 to 2018) of the study of documents on emergeing technologies in the educational context in the area of social sciences. This panorama, in relation to the public criteria, is shaped by studies ( 43 publications) where the predominant sample consists of students of higher education, followed by secondary education students. On the other hand, there is less research carried out in the context of primary and infant education, reaffirming as initial conclusions a greater development of the studies in the university context. As for the topics, 29 publications refer to collaborative learning, 23 refer to learning analytics, 15 refer to profound learning, followed by 10 documents on adaptative learning and 13 documents on e-learning. The predominant methodological design refers to empirical studies with quantitative techniques (31 publications) followed by the mixed studies (20), along with the qualitative studies(11), in accordance with the established categorization and synthesis of information (Wollscheid, Sjaastad \& Tømte, 2016) in the documentary analysis. Finally, regarding the conclusions criteria, 38 publications reiterate the learning outcomes of the different documents assessed, followed by 24 documents on various learning achievements. Regarding the teacher professional performance and the implementation of ICT in real-life contexts, 5 documents are analyzed, providing results in each 
of them. Lastly, 4 documents highlight the performance assessment, along with 3 documents that focus on the design of resources.

The effects of the research carried out with the students show mainly benefits in most of the analyzed works, bringing new insights into the subject: the collaborative work in problem solving. On the other hand, the use of educational games together with the development of learning analytics allow to discover factors that affect the learning outcomes of the students, as well as the possibility of making adaptations focused on educational inclusion, and detecting aspects that promote or prevent its applicability (Hernández-Lara, Perera-Lluna, \& Serradel-López, 2018; Nyugen, Gardner, \& Sheridan, 2018; Rodríguez-Triana, Martínez-Monés, \& Villagrá-Sobrino, 2015).

Regarding students' behaviors and attitudes within the studies analyzed, more research is needed to justify the effect of the technologies assessed on learning and student behavior patterns. San Pedro, Baker, \& Hefferman (2017) insist on the need to include emotions as determinants, as well as previous learning experiences (Biggs, \& Tang, 2007; Pegrum, Bartle, \& Longnecker, 2015), to offer a more holistic view of the academic life of the students, taking into account the cognitive abilities they develop. The inverted classroom has proved to promote profound learning approaches, since it is based on the development of problem-solving skills, collaboration and higher order thinking operations (Baytiyeh \& Naja, 2017; McLean, Attardi, Fades, \& Goldszmidt, 2016).

Meanwhile, there is a high level of co-authorship in the degree of collaboration of the studies, with a collaboration degree of 0.96 , ehat leads us to think that $96 \%$ of the studies have been carried out in collaboration, due to the nature of the research problem and/or the financial support, a result of subsidized research projects (Subramanyam, 1983), in line with a high visibility and quotation of the selected studies.

Limitations include the difficulty of nesting some documents of the research based on the inclusion criteria; lack of studies in educational levels of primary education and infant education, being the majority of the target students of higher education. In addition, it is worth mentioning the variability observed in the study samples, as there were large differences in the typology of the studies analyzed.

\section{References}

Adams Becker, S., Cummins, M., Freeman, A., Giesenger Hall, C., \& Yuhnke, B. (2016). NMC Horizon Report: 2016 K-12 Edition. (pp. 1-49). Austin, Texas: The New Media Consortium. Recuperado de http://cdn.nmc.org/media/2016-nmc-cosn-horizon-report-k12-EN.pdf

Adams Becker, S., Cummins, M., Freeman, A., Giesinger Hall, C., \& Ananthanarayanan, V. (2017). NMC Horizon Report: Higher Education Edition (pp. 1-56). Austin, Texas: The New Media Consortium. Recuperado de http://cdn.nmc.org/media/2017-nmc-horizon-report-he-EN.pdf

Adner, R., \& Levinthal, D. A. (2002). The emergence of emerging technologies. California Management Review, 45(1), 50-66. Recuperado de https://journals.sagepub.com/doi/pdf/10.2307/41166153?casa_token=QhkZSixBAjkAAAAA\%3A_IE5 RZWxuI7hGbzBa3o7m5TO-t2DwhUNobkRgoIrTudYtCICL_6zgp16XWidPoOo3qB_Egu4Y3XAkg

Aguaded, I., Vázquez-Cano, E. \& López-Meneses, E. (2016). El impacto bibliométrico del movimiento MOOC en la Comunidad Científica Española. Educación XX1, 19(2), 77-104, doi: 10.5944/educXX1. 13217

Akhtar, S., Warburton, S., \& Xu, W. (2017). The use of an online learning and teaching system for monitoring computer aided design student participation and predicting student success. International Journal of Technology and Design Education, 27(2), 251-270. https://doi.org/10.1007/s10798-015-9346-8

Avila-Robinson, A., \& Miyazaki, K. (2011). Conceptualization and operationalization of emerging technologies: A complementing approach. En 2011 Proceedings of PICMET '11: Technology Management in the Energy Smart World (PICMET) (pp. 1-12).

Baker, R. S., \& Inventado, P. S. (2014). Educational Data Mining and Learning Analytics. En J. A. Larusson \& B. White (Eds.), Learning Analytics: From Research to Practice (pp. 61-75). New York, NY: Springer New York. https://doi.org/10.1007/978-1-4614-3305-7_4

Baytiyeh, H., \& Naja, M. K. (2017). Students' perceptions of the flipped classroom model in an engineering 
course: a case study. European Journal of Engineering Education, 42(6), 1048-1061. https://doi.org/10.1080/03043797.2016.1252905

Berners Lee, T., Cailliau, R., Pollermann, B., \& Groff, J. (1992). World Wide Web: The Information Universe. Internet Research, 2(1), 52-58. https://doi.org/10.1108/eb047254

Bettencourt, L., Kaiser, D., Kaur, J., Castillo-Chávez, C., \& Wojick, D. (2008). Population modeling of the emergence and development of scientific fields. Scientometrics, 75(3), 495-518. https://doi.org/10.1007/s11192-007-1888-4

Biggs, J., \& Tang, C. (2007). Setting the stage for effective teaching. Teaching for quality learning at university, 31-59.

Boyack, K. W., Small, H., \& Klavans, R. (2013). Improving the accuracy of co-citation clustering using full text. Journal of the American Society for Information Science and Technology, 64(9), 1759-1767. https://doi.org/10.1002/asi.22896

Brooks, C., Greer, J., \& Gutwin, C. (2014). The Data-Assisted Approach to Building Intelligent TechnologyEnhanced Learning Environments. En J. A. Larusson \& B. White (Eds.), Learning Analytics: From Research to Practice (pp. 123-156). New York, NY: Springer New York. https://doi.org/10.1007/9781-4614-3305-7_7

Castellon-Fuentes, J. D., Morente-Molinera, J. A., Herrera-Viedma, E., \& Lopez-Herrera, A. G. (2013). A New Moodle Module for Interactive Video-Lessons: An Adaptative Way to Follow a Course. En L. G. Chova, A. L. Martinez, \& I. C. Torres (Eds.), 7th International Technology, Education and Development Conference (inted2013). Valenica: Iated-Int Assoc Technology Education a\& Development.

Choi, G. W., Land, S. M., \& Zimmerman, H. T. (2018). Investigating children's deep learning of the tree life cycle using mobile technologies. Computers in Human Behavior, 87, 470-479. https://doi.org/10.1016/j.chb.2018.04.020

Clarivate Analytics. (2018). WOS-basic search. Recuperado 26 de noviembre de 2018, de https://apps.webofknowledge.com/WOS_GeneralSearch_input.do?product=WOS\&search_mode=Gen eralSearch\&SID=D2ajRUcJRO4Q0SbDj10\&preferencesSaved $=$

Clow, D. (2013). An overview of learning analytics. Teaching in Higher Education, 18(6), 683-695. https://doi.org/10.1080/13562517.2013.827653

Day, G. S., Schoemaker, P. J. H., \& Gunther, R. E. (2004). A perfect game. En Wharton on Managing Emerging Technologies (pp. 1-23). New Jersey: John Wiley \& Sons.

De Backer, L., Van Keer, H., Moerkerke, B., \& Valcke, M. (2016). Examining evolutions in the adoption of metacognitive regulation in reciprocal peer tutoring groups. Metacognition and Learning, 11(2), 187213. https://doi.org/10.1007/s11409-015-9141-7

De Corte, E. (2015). Constructive, self-regulatory, situated and collaborative learning: an approach to the acquisition of the adaptative competency in mathematics. Paginas De Educacion, 8(2).

Dietz-Uhler, B., \& Hurn, J. E. (2013). Using learning analytics to predict (and improve) student success: A faculty perspective. Journal of Interactive Online Learning, 12(1), 17-26.

European Comission. (2018). Digital Education Action Plan (Communication from the Commission to the European Parliament, the Council, the European Economic and Social Committee and the Committee of the Regions). Brussels: European Union. Recuperado de https://eur-lex.europa.eu/legalcontent/EN/TXT/PDF/?uri=CELEX:52018DC0022\&from =EN

Freeman, A., Adams Becker, S., Cummins, M., Davis, A., \& Giesinger Hall, C. (2017). NMC Horizon Report: 2017 K-12 Edition. (pp. 1-55). Austin, Texas: The New Media Consortium. Recuperado de http://cdn.nmc.org/media/2016-nmc-cosn-horizon-report-k12-EN.pdf

Garcia-Ros, R., \& Perez-Gonzalez, F. (2011). Assessment preferences of preservice teachers: analysis according to academic level and relationship with learning styles and motivational orientation. Teaching in Higher Education, 16(6), 719-731. https://doi.org/10.1080/13562517.2011.570434

Geels, F. W. (2005). Processes and patterns in transitions and system innovations: Refining the co-evolutionary multi-level perspective. Technological Forecasting and Social Change, 72(6), 681-696. https://doi.org/10.1016/j.techfore.2004.08.014

Giardina, M. (1998). A distributed interaction model for the development of intelligent networked learning diagnostic system. (T. W. Chan, A. Collins, \& J. X. Lin, Eds.). Beijing: China Higher Education Press Beijing.

Glänzel, W., \& Thijs, B. (2011). Using 'core documents' for detecting and labelling new emerging topics. Scientometrics, 91(2), 399-416. https://doi.org/10.1007/s11192-011-0591-7

Halaweh, M. (2013). Emerging Technology: What is it? Journal of Technology Management \& Innovation, 8(3), 108-115. https://doi.org/10.4067/S0718-27242013000400010

Hernández-Lara, A. B., Perera-Lluna, A., \& Serradell-López, E. (2018). Applying learning analytics to students' interaction in business simulation games. The usefulness of learning analytics to know what students really learn. Computers in Human Behavior. https://doi.org/10.1016/j.chb.2018.03.001 
Houghton, W. (2004). Deep and surface approaches to learning. Engineering Subject Centre Guide: Learning and Teaching Theory for Engineering Academics, W. Houghton, ed. Loughborough, UK: HEA Engineering Subject Centre.

Howard, C., Di Eugenio, B., Jordan, P., \& Katz, S. (2017). Exploring Initiative as a Signal of Knowledge CoConstruction During Collaborative Problem Solving. Cognitive Science, 41(6), 1422-1449. https://doi.org/10.1111/cogs.12415

Jiménez-Fanjul, N. (2016). Producción científica internacional en Educación Matemática. Estudio bibliométrico (1983-2012). Tesis doctoral. Universidad de Córdoba. Córdoba. http://hdl.handle.net/10396/13759

Johnson, L., Adams Becker, S., Cummins, M., Estrada, V., \& Freeman, A. (2014). NMC Horizon Report: 2014 K12 Edition. (pp. 1-48). Austin, Texas: The New Media Consortium. Recuperado de http://cdn.nmc.org/media/2014-nmc-horizon-report-k12-EN.pdf

Johnson, L., Adams Becker, S., Cummins, M., Estrada, V., Freeman, A., \& Ludgate, H. (2013a). NMC Horizon Report: 2013 K-12 Edition. (pp. 1-40). Austin, Texas: The New Media Consortium. Recuperado de https://www.nmc.org/pdf/2013-horizon-report-k12.pdf

Johnson, L., Adams Becker, S., Cummins, M., Estrada, V., Freeman, A., \& Ludgate, H. (2013b). NMC Horizon Report: Higher Education Edition. (UNIR, Trad.) (pp. 1-46). Austin, Texas: The New Media Consortium. Recuperado de https://www.nmc.org/pdf/2013-Horizon-Report-HE-ES.pdf

Johnson, L., Adams Becker, S., Estrada, V., \& Freeman, A. (2014). NMC Horizon Report: Higher Education Edition (pp. 1-48). Austin, Texas: The New Media Consortium. Recuperado de http://cdn.nmc.org/media/2014-nmc-horizon-report-he-EN-SC.pdf

Johnson, L., Adams Becker, S., Estrada, V., \& Freeman, A. (2015). NMC Horizon Report: Higher Education Edition (pp. 1-49). Austin, Texas: The New Media Consortium. Recuperado de http://cdn.nmc.org/media/2015-nmc-horizon-report-HE-EN.pdf

Johnson, L., Adams Becker, S., Estrada, V., Freeman, A., \& Giesinger Hall, C. (2016). NMC Horizon Report: Higher Education Edition (pp. 1-49). Austin, Texas: The New Media Consortium. Recuperado de http://cdn.nmc.org/media/2016-nmc-horizon-report-he-EN.pdf

Kacfah Emani, C., Cullot, N., \& Nicolle, C. (2015). Understandable Big Data: A survey. Computer Science Review, 17, 70-81. https://doi.org/10.1016/j.cosrev.2015.05.002

Kirkwood, A., \& Price, L. (2013). Examining some assumptions and limitations of research on the effects of emerging technologies for teaching and learning in higher education. British Journal of Educational Technology, 44(4), 536-543. https://doi.org/10.1111/bjet.12049

Leu, D. J., Kinzer, C. K., Coiro, J. L., \& Cammack, D. W. (2004). Toward a theory of new literacies emerging from the Internet and other information and communication technologies. En Theoretical models and processes of reading (5th ed., pp. 1570-1613). Recuperado de https://s3.amazonaws.com/academia.edu.documents/39882371/Toward_a_Theory_of_New_Literaci es_Emergi20151110-27533-

1mpueq6.pdf?AWSAccessKeyId=AKIAIWOWYYGZ2Y53UL3A\&Expires $=1543232526 \&$ Signature $=\% 2 \mathrm{Be}$ sAiKLgtqjNkXa6\%2BEdtHuVGxi0\%3D\&response-content-

disposition=inline\%3B\%20filename\%3DToward_a_theory_of_new_literacies_emergi.pdf

Manca, S. (2018). ResearchGate and Academia.edu as networked socio-technical systems for scholarly communication: a literature review. Research in Learning Technology, 26. https://dx.doi.org/10.25304/rlt.v26.2008

Manjarres, A. V., Sandoval, L. G. M., \& Suárez, M. J. S. (2018a). Data mining techniques applied in educational environments: Literature Review. Digital Education Review, O(33), 235-266. Recuperado de http://revistes.ub.edu/index.php/der/article/view/18067

Manjarres, A. V., Sandoval, L. G. M., \& Suárez, M. J. S. (2018b). Data mining techniques applied in educational environments: Literature Review. Digital Education Review, 0(33), 235-266. Recuperado de http://revistes.ub.edu/index.php/der/article/view/18067

Markard, J., Raven, R., \& Truffer, B. (2012). Sustainability transitions: An emerging field of research and its prospects. Research Policy, 41(6), 955-967. https://doi.org/10.1016/j.respol.2012.02.013

Martin, B. R. (1995). Foresight in science and technology. Technology Analysis \& Strategic Management, $7(2)$, 139-168. https://doi.org/10.1080/09537329508524202

Martin, B. R. (2010). The origins of the concept of 'foresight' in science and technology: An insider's perspective. Technological Forecasting and Social Change, 77(9), 1438-1447. https://doi.org/10.1016/j.techfore.2010.06.009

McLean, S., Attardi, S. M., Faden, L., \& Goldszmidt, M. (2016). Flipped classrooms and student learning: not just surface gains. Advances in Physiology Education, 40(1), 47-55. https://doi.org/10.1152/advan.00098.2015

Nguyen, A., Gardner, L. A., \& Sheridan, D. (2018). A framework for applying learning analytics in serious 
games for people with intellectual disabilities. British Journal of Educational Technology, 49(4), 673689. https://doi.org/http:/doi.org/10.1111/bjet.12625

O'Brien, J. (2018). NMC Horizon Report 2018 Higher Education | \#EnlightED. Madrid: La Nave. Recuperado de https://www.youtube.com/watch?v=_FOfvxZzZL8

Nupur, C. (2014). World Wide Web and its jpurney from web 1.0 to web 4.0. International Journal of Computer Science and Information Technologies, 5(6), 8096-8100. Recuperado de http://citeseerx.ist.psu.edu/viewdoc/download?doi=10.1.1.666.6445\&rep=rep1\&type=pdf

Pegrum, M., Bartle, E., \& Longnecker, N. (2015). Can creative podcasting promote deep learning? The use of podcasting for learning content in an undergraduate science unit. British Journal of Educational Technology, 46(1), 142-152. https://doi.org/10.1111/bjet.12133

Philip Chen, C. L., \& Zhang, C.-Y. (2014). Data-intensive applications, challenges, techniques and technologies: A survey on Big Data. Information Sciences, 275, 314-347. https://doi.org/10.1016/j.ins.2014.01.015

Pina, A. R. B., Torlà, C. B., Quintero, L. C., \& Segura, J. A. (2017). Blockchain en Educación: introducción y crítica al estado de la cuestión. Edutec. Revista Electrónica de Tecnología Educativa, 0(61), 363. https://doi.org/10.21556/edutec.2017.61.915

Porter, A. L. (2004). Technology futures analysis: Toward integration of the field and new methods. Technological Forecasting and Social Change, 71(3), 287-303. https://doi.org/10.1016/j.techfore.2003.11.004

Porter, A. L., \& Detampel, M. J. (1995). Technology opportunities analysis. Technological Forecasting and Social Change, 49(3), 237-255. https://doi.org/10.1016/0040-1625(95)00022-3

Prendes, M. P. (2018). La Tecnología Educativa en la Pedagogía del siglo XXI: una visión en 3D. Revista Interuniversitaria de Investigación en Tecnología Educativa, (4), 6-16. http://dx.doi.org/10.6018/riite/2018/335131

Rodriguez Triana, M. J., Martínez-Monés, A., \& Villagrá-Sobrino, S. (2015). Applying Learning Analytics to a Primary School Classroom: Benefits and Barriers. Recuperado de https://infoscience.epfl.ch/record/210524

Rogers, P. L. (2000). Barriers to Adopting Emerging Technologies in Education. Journal of Educational Computing Research, 22(4), 455-472. https://doi.org/10.2190/4UJE-B6VW-A30N-MCE5

Rotolo, D., Hicks, D., \& Martin, B. R. (2015). What is an emerging technology? Research Policy, 44(10), 18271843. https://doi.org/10.1016/j.respol.2015.06.006

Sampieri, R., Collado, C., \& Lucio, P. (2014). Metodología de la investigación. Nueva York: Editorial McGrawHill.

San Pedro, M. O. Z., Baker, R. S., \& Heffernan, N. T. (2017). An Integrated Look at Middle School Engagement and Learning in Digital Environments as Precursors to College Attendance. Technology Knowledge and Learning, 22(3), 243-270. https://doi.org/10.1007/s10758-017-9318-z

Shen, Y.-C., Chang, S.-H., Lin, G. T. R., \& Yu, H.-C. (2010). A hybrid selection model for emerging technology. Technological Forecasting and Social Change, 77(1), 151-166. https://doi.org/10.1016/j.techfore.2009.05.001

Small, H. (2006). Tracking and predicting growth areas in science. Scientometrics, 68(3), 595-610. https://doi.org/10.1007/s11192-006-0132-y

Small, H., Boyack, K. W., \& Klavans, R. (2014). Identifying emerging topics in science and technology. Research Policy, 43(8), 1450-1467. https://doi.org/10.1016/j.respol.2014.02.005

Smith, K. (2018). Perceptions of Preservice Teachers about Adaptive Learning Programs in K-8 Mathematics Education. Contemporary Educational Technology, 9(2), 111-130. https://doi.org/10.30935/cet.414780

Srinivasan, R. (2008). Sources, characteristics and effects of emerging technologies: Research opportunities in innovation. Industrial Marketing Management, 37(6), 633-640. https://doi.org/10.1016/j.indmarman.2007.12.003

Stahl, B. C. (2011). What Does the Future Hold? A Critical View of Emerging Information and Communication Technologies and Their Social Consequences. En M. Chiasson, O. Henfridsson, H. Karsten, \& J. I. DeGross (Eds.), Researching the Future in Information Systems (Vol. 356, pp. 59-76). Berlin: Springer. https://doi.org/10.1007/978-3-642-21364-9_5

Suárez-Manzano, S., Ruiz-Ariza, A., De La Torre-Cruz, M., \& Martínez-López, E. J. (2018). Acute and chronic effect of physical activity on cognition and behaviour in young people with ADHD: A systematic review of intervention studies. Research in developmental disabilities, 77, 12-23. https://doi.org/10.1016/j.ridd.2018.03.015

Subramanyam, K. (1983). Bibliometric studies of research collaboration: A review. Journal os Information Science, 6, 33-38. 
The Business Dictionary. (2018). What are emerging technologies? definition and meaning. Recuperado 26 de noviembre de 2018, de http://www.businessdictionary.com/definition/emerging-technologies.html

Torres-Toukoumidis, Romero-Rodríguez \& Pérez-Rodríguez (2018). Ludificación y sus posibilidades en el entorno de blended learning: revisión documental, RIED. Revista Iberoamericana de Educación a Distancia, 21(1), 95-111. DOI: http://dx.doi.org/10.5944/ried.21.1.18792

UNESCO. (2015). Qingdao Declaration (Seize digital opportunities, lead education transformation) (pp. 1-54). Qindgao, China:

UNESCO.

Recuperado

de http://unesdoc.unesco.org/images/0023/002333/233352m.pdf

Viberg, O., Hatakka, M., Balter, O., \& Mavroudi, A. (2018). The current landscape of learning analytics in higher education. Computers in Human Behavior, 89, 98-110. https://doi.org/10.1016/j.chb.2018.07.027

Wise, A. F. (2014). Designing Pedagogical Interventions to Support Student Use of Learning Analytics. En Proceedings of the Fourth International Conference on Learning Analytics And Knowledge (pp. 203211). New York, NY, USA: ACM. https://doi.org/10.1145/2567574.2567588

Wollscheid, S., Sjaastad, J., \& Tømte, C. (2016). The impact of digital devices vs. Pen (cil) and paper on primary school students' writing skills-A research review. Computers \& Education, 95, 19-35. DOI: https://doi.org/10.1016/j.compedu.2015.12.001

Xing, W., Guo, R., Petakovic, E., \& Goggins, S. (2015). Participation-based student final performance prediction model through interpretable Genetic Programming: Integrating learning analytics, educational data mining and theory. Computers in Human Behavior, 47, 168-181. https://doi.org/10.1016/j.chb.2014.09.034

Zilvinskis, J., Willis, J., \& Borden, V. M. H. (2017). An Overview of Learning Analytics. New Directions for Higher Education, 2017(179), 9-17. https://doi.org/10.1002/he.20239

Zniber, N. (2011). Pops: A Service-Oriented Approach for Composing Personalized Courses. In L. G. Chova, I. C. Torres, \& A. L. Martinez (Eds.), INTED2011 Proceedings (pp.2951-2961). Valencia: Iated-Int Assoc Technology Education \& Development. 